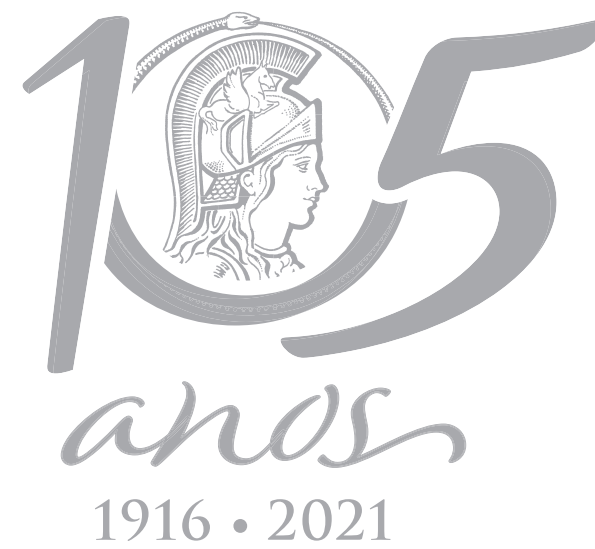

$1916 \cdot 2021$

\title{
ECOSYSTEMS
}

\section{Transplanting macrophytes as a rehabilitation technique for lowland streams and their influence on macroinvertebrate assemblages}

\author{
PAULA ALTIERI, LAURA E. PAZ, ROBERTO F. JENSEN, JORGE DONADELLI \& \\ ALBERTO RODRIGUES CAPÍTULO
}

\begin{abstract}
Lowland streams are usually affected by river engineering works that produce the loss of habitat heterogeneity. Our aim was to assess the transplantation of macrophytes with different complexity into a lowland stream which was dredged and widened. Stuckenia pectinata and Hydrocleys nymphoides were collected at an extraction site and installed at a transplant site. The growth and coverage of macrophytes beds were quantified. Taxonomic richness, Shannon-Wiener diversity, abundance, composition and proportion of functional feeding groups of the macroinvertebrate assemblage presented in macrophyte beds were assessed between sites and species. The growth of both macrophytes did not differ significantly between sites and the coverage of transplanted beds increased, therefore they established at the transplant site within a short period. Regarding to macroinvertebrate assemblage, only the functional feeding groups did not show differences between sites. Moreover, the proportion of predators presented differences between macrophytes at the same site, with $H$. nymphoides having a higher proportion. Our study showed that this technique is suitable for reintroducing these species and is applicable in rehabilitation projects that promote the restoration of habitat heterogeneity deteriorated by river engineering works. Also, we highlight the importance of incorporate macroinvertebrate functional traits to assess the ecological status after rehabilitation.
\end{abstract}

Key words: restoration, aquatic plants, macroinvertebrates, Stuckenia pectinata, Hydrocleys nymphoides.

\section{INTRODUCTION}

Although streams and wetlands provide essential biological and economic services (Millennium Ecosystem Assessment Board 2005), over the last century they have been seriously threatened by human activity, such as water quality degradation and flow regulation (Allan 2004, Elosegi et al. 2010). The implementation of river engineering projects produce significant changes in flow velocity and erosion of bed and bank material (Elosegi \& Sabater 2013). As a consequence, streams have lost their habitat heterogeneity and have become deeper and wider (Brooker 1985, Elosegi et al. 2010). Moreover, these practices have had negative effects on birds, fish, phytoplankton, and periphytic and epipelic algae assemblages and have caused reductions in the density of invertebrates and the loss of aquatic plants (Lewis et al. 2001, Licursi \& Gómez 2009, Cabrita 2014, Grygoruk et al. 2015, Kjelland et al. 2015).

Currently, lowland streams are usually highly modified and managed predominantly for their drainage roles (Licursi \& Gómez 2009, Suren 2009). These streams are characterised by 
the development of dense and rich macrophyte assemblages (Giorgi et al. 2005, Rodrigues Capítulo et al. 2010). However, because of river engineering works, they have lost these assemblages and the channel simplification has reduced the probability of their recolonization by fragments of plants or seeds (propagules, Riis 2008).

Macrophytes have been described as biological engineers (Sand-Jensen 1997). They affect the sediment and nutrient dynamics, and are highly efficient at removing a variety of contaminants from the water (GuittonnyPhilippe et al. 2015, Bonanno et al. 2017). Furthermore, macrophytes increase the physical complexity of the streams and provide habitat for macroinvertebrates (Cortelezzi et al. 2013). The effect of aquatic macrophytes on their associated macroinvertebrate assemblage depends on their structural complexity, also known as architecture (Lillie \& Budd 1992). Complex macrophytes can increase the resources for macroinvertebrates, like microhabitats (Mcnett \& Rypstra 2000), protection against predators (Warfe \& Bermuta 2004) and food (Phiri et al. 2012). Therefore, complex macrophytes may support higher abundance and richness of macroinvertebrate than simple macrophytes (Taniguchi et al. 2003, Warfe et al. 2008, Cremona et al. 2008).

Despite the numerous benefits that aquatic plants provide to lowland streams and their potential for rehabilitation, only a few studies have assessed the feasibility of their reintroduction by transplantation in these water courses (Larned et al. 2006, Riis et al. 2009, Suren 2009, Paz et al. 2018). These studies have reported contradictory results, depending on the macrophytes species and stream conditions. Therefore, itis necessaryto improvethistechnique for future restoration projects. Moreover, it is important to evaluate the ecological status of watercourses after rehabilitation; for this purpose, macroinvertebrates are considered good indicators of changes in the environment (Bonada et al. 2006, dos Reis Oliveira et al. 2019). This assemblage is an essential component of the aquatic ecosystem because contribute to the processing of particulate organic matter, regulating primary production and providing food for fishes (Reece \& Richardson 2000, Spänhoff \& Arle 2007).

We analyzed the growth and the changes in macroinvertebrate assemblage of two transplanted macrophytes with different structural complexity in a stream modified by river engineering works. We used the richness, diversity, abundance, and proportion of functional feeding groups (FFGs) to evaluate the changes in macroinvertebrate assemblage after the transplant. Our hypotheses were: 1-both macrophytes grow after the transplant, 2- the macroinvertebrate assemblage descriptors do not differ between transplanted and extraction (control) sections and 3- more complex macrophytes present high richness, diversity, and proportion of FFGs of macroinvertebrates.

Our results will be useful not only to improve the transplantation technique for future management and rehabilitation of lowland streams but also contribute to understand how macroinvertebrate assemblages change depending on macrophyte complexity.

\section{MATERIALS AND METHODS}

\section{Study area}

The experiment was conducted in 2015, in a lowland stream of the Pampean ecoregion, which is located in central eastern Argentina. The Martín stream, a second-order watercourse (Figure 1), that has been affected by river engineering works. As a result, this stream has a highly simplified and uniform channel. This stream mainly crosses a suburban area and the 


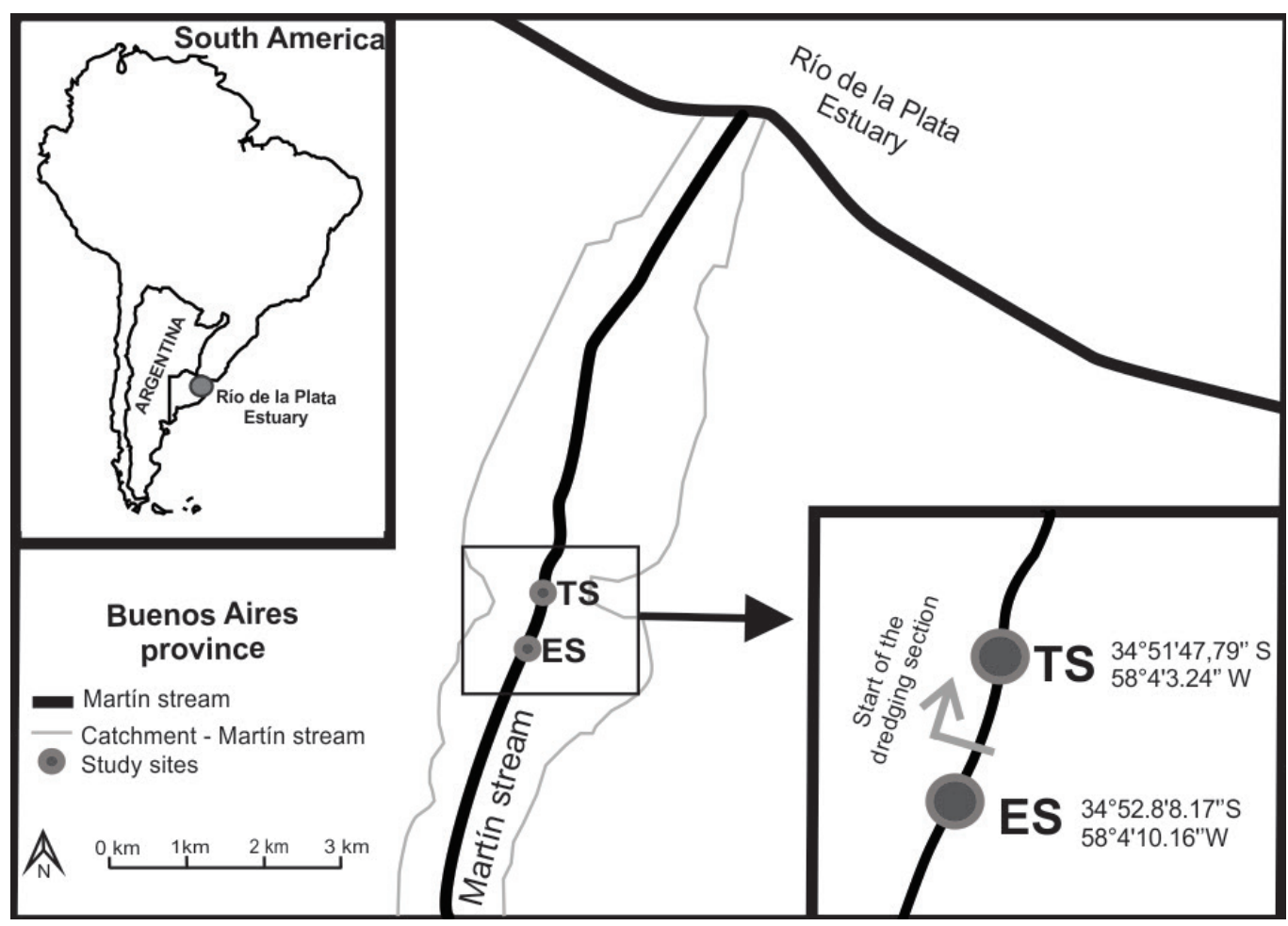

Figure 1. Map of the study area showing the location of the transplant site (TS) and the extraction site (ES), modified from Hurtado et al. 2006.

land use in the catchment is mainly peri-urban and agricultural (Cochero et al. 2015).

Two sites were established in a section of the Martin stream that cross the Municipal Ecological Park in La Plata. One was located upstream where macrophytes were collected (extraction site, ES); this site was characterised by a high coverage of aquatic plants, a pronounced sinuosity and availability of source populations of colonists. The other site (transplant site, TS), which was downstream, had recently been deepened, widened and straightened. Additionally, the aquatic plants had been removed from the stream bed and as a result, the heterogeneity was decreased. The transplant site was characterised as shallower (depth $=0.28 \pm 0.07 \mathrm{~m}$ ) and narrower (width = $14.97 \pm 0.47 \mathrm{~m}$ ) than the ES (depth $=0.06 \pm 0.02 \mathrm{~m}$ and width $=11.2 \pm 5.49 \mathrm{~m}$ ).

In each sampling site, macrophytes and macroinvertebrates were sampled four times (every 20 days) from October to November (spring). The first sampling occasion occurred immediately after transplant (day 0).

\section{Selected macrophytes}

We selected two abundant species at ES, Stuckenia pectinata (L.) Börner [= Potamogeton pectinatus (L.)] (fennel pondweed, Potamogetonaceae) and Hydrocleys nymphoides (Hump. and Bonpl. ex Willd.) Buchenau (waterpoppy, Alismataceae). However, before starting the experiment, we calculated their fractal dimension (D) using Image software (Rasband 1997-2008, Ferreiro et al. 2011) to verify that they had different complexities. We found that S. pectinata is more complex than $\mathrm{H}$. nymphoides ( $D=1.63$ and $D=1.53$, respectively).

\section{Transplantation of aquatic plants}

We collected specimens of the two species from the ES with a garden spade, taking care not to damage the roots and shoots, and placed them in trays $(45 \times 35 \times 10 \mathrm{~cm}$; Riis et al. 2009, Paz et 
al. 2018, Figure 2a). The total area transplanted was of $0.05 \mathrm{~m}^{2}$ in the case of S. pectinata, and $0.26 \mathrm{~m}^{2}$ in the case of $\mathrm{H}$. nymphoides. In order to exclude the effect of the substrate, sediment from the same stream was used to line the trays (Riis et al. 2009, Choudhury et al. 2015). The trays were immediately installed at the TS, forming three beds of approximately $135 \times 105$ $\mathrm{cm}$ by species (two trays conformed one bed); they were planted in the stream at depths of 0.20 to $0.40 \mathrm{~m}$, depending on the species. Mean water velocity was between 0.04 and $0.09 \mathrm{~m} \mathrm{~s}^{-1}$ to ensure favorable light exposure and conditions (Lauridsen et al. 2003).

The transplantation was carried out following the recommendations of Riis et al. (2009): a) choosing a stream with shallow water $(<1 \mathrm{~m})$ and unshaded conditions for sustainable macrophytes growth, b) selecting macrophytes naturally present in the region and in upstream reaches, c) using trays of at least $20 \times 30 \times$ $5 \mathrm{~cm}$, and d) transplanting during the growth season. The distribution pattern of the trays was selected following the recommendations of Bal et al. (2011) (Figure 2b).

\section{Macrophytes monitoring and analysis}

To evaluate macrophytes growth, 12 specimens of each species (at both sites) were marked. The shoot length of each specimen (SL) was measured throughout the experiment and growth was calculated as increase in length (LI) $(\mathrm{LI}[\mathrm{cm}]=$ final $\mathrm{SL}$ - initial SL) (Choudhury et al. 2015).

Coverage of each transplanted bed was calculated following the methodology proposed by Pan et al. (2007). A series of images captured by a Nikon 3100 camera on each sampling date were taken, including cover at the TS immediately after transplantation. These images were processed using ImageJ version $1.51 \mathrm{R}$. to quantify the coverage of each bed. The increase in coverage $\left(\mathrm{m}^{2}\right)$ was calculated based on the difference between the final and initial cover of each bed and for both species ( $\triangle$ Coverage $\left[\mathrm{m}^{2}\right]=$ final coverage - initial coverage).

a)

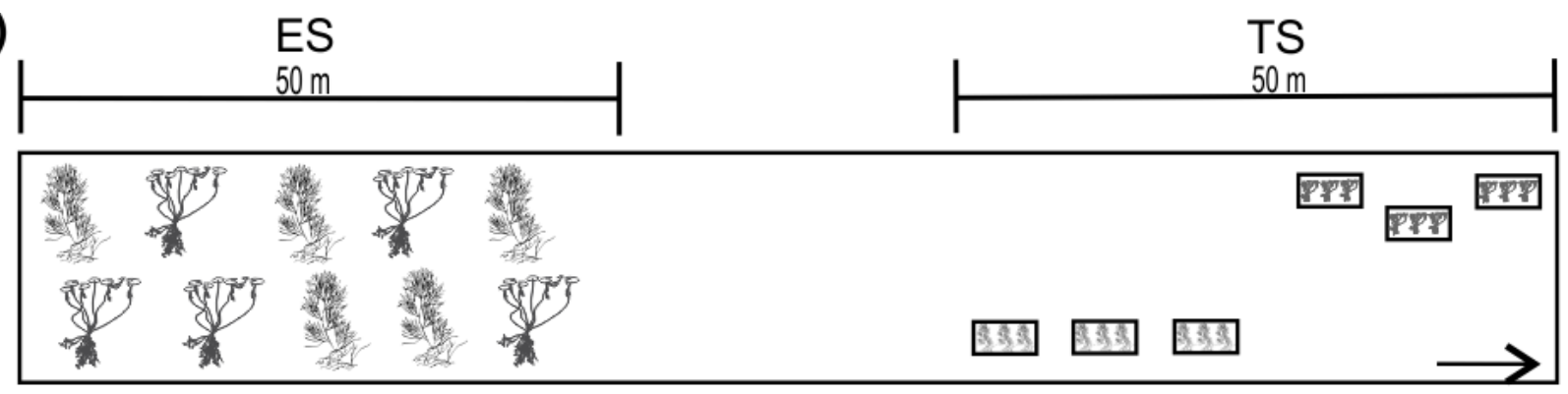

b)

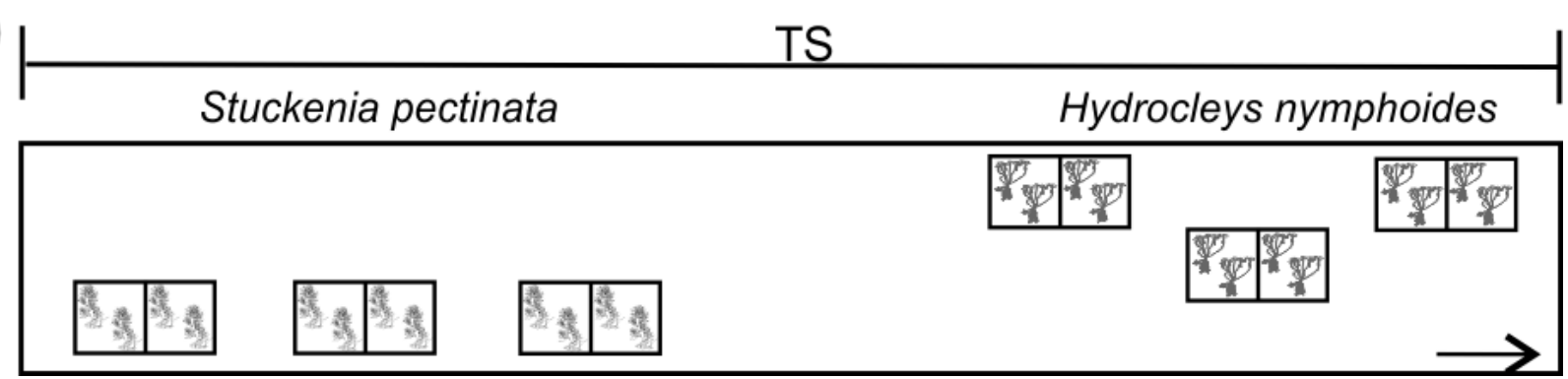

Figure 2. Tray distribution in the stream: a) plan view of tray distribution in the section of Martín Stream showing the extraction site (ES) and transplant site (TS); b) section of the TS magnified with details of the trays' disposition. The arrows indicate the direction of flow. 


\section{Macroinvertebrate assemblages}

We collected one replicate from each macrophyte bed (three beds per species) using a hand net $\left(0.018 \mathrm{~m}^{2} ; 500 \mu \mathrm{m}\right.$ pore size) at both sites and on each sampling occasion. The samples were fixed in situ with 5\% formaldehyde and the organisms sorted. In the laboratory, the specimens were counted and identified under a stereomicroscope to the lowest possible taxonomic level using taxonomic keys (Barbour et al. 1999).

We calculated the taxonomic richness and Shannon-Wiener diversity index and we assigned each taxa to a functional feeding group (FFG) using available references (Cummins et al. 2005, Allan \& Castillo 2007, Merritt et al. 2008). The relative frequency values of each FFG at each site and on each sampling occasion were calculated using macroinvertebrate densities (ind $\mathrm{m}^{-2}$ ).

\section{Data analysis}

We performed a Student's $t$-test $(\alpha=0.05)$ to compare macrophyte growth (LI) between sites. The comparisons between species was not possible due to both macrophytes have different life form. However, we only analyzed the values up to day 40 because all the marks on the specimens were lost. Additionally, two of the three transplanted beds of S. pectinata were damaged by acts of vandalism, which caused the loss of one of the two trays of each bed. The damage prevented calculation of the coverage of these beds, but sampling was performed in the remaining tray of each bed.

We analyzed Shannon-Wiener diversity index at both sites and macrophytes with a linear model and a Gaussian error distribution (link: identity). Models for Taxonomic richness and each FFG were first fitted with a Gaussian error distribution (link: identity), since model residuals were not normally distributed
(Shapiro test: $p<0.01$ ), they were refitted using alternative distributions more suited to the response data. Specifically, we used generalized models with the Poisson error distribution for Taxonomic richness (link: log) and Binomial error distribution (link = logit) for FFG proportions.

The predictor variables were the macrophyte species (S. pectinanta and $H$. nymphoides), time (days 0, 20, 40, and 60), sites (ES and TS) and its interactions. All models were fitted with a random effect "patches" (intercept) because of the lack of independence of the data. We considered models with all possible combinations of predictor variables and evaluated the models using Akaike's Information Criterion corrected for small sample size (AICC) (Burnham \& Anderson 2002). This resulted in 10 candidate models for each response variable corresponding to all possible combinations including one general model with all predictors (global model) and a base model without predictors (null model). A null model was useful for assessing the relative explanatory power of models containing predictors of interest. Model comparisons were made with $\triangle \mathrm{AICC}$, which is the difference between the lowest AICc value (i.e., best of suitable models) and AICc from all other models. Models with $\triangle \mathrm{AICC} \leq 2$ have substantial support from the data (Burnham \& Anderson 2002). The AlCc weight of each model (wi) was also calculated to evaluate support for estimates of predictor variables, parameters with good support have high wi values (near to 1). Once we selected the suitable model, we calculated 95\% confidence intervals of parameter estimates and performed a Tukey test to determine differences between levels of the fixed variable

To analyze the composition of macroinvertebrate assemblage for each sampling day, site and macrophyte we performed a multidimensional scaling (MDS), in this case we performed a Principal Coordinate Analysis (PCOA). 
Since our data set was zero inflated because of a large number of real zeros and species with high densities was necessary to carried out a standardization process. We consider that the most appropriate was the standardization by ranges (0-1). This standardization leads the data to a range between 0 and 1 allowing comparison without masking the existing differences. Onces the data was standardized used ranges, Euclidean distance could be used for the analysis, this distance meets all the mathematical properties which is more in order to our objectives. Additionally, we tested significative differences among all samples from sites and macrophytes using a "Permutational Multivariate Analysis of Variance" (PERMANOVA, 999 random permutation) with Bonferroni correction.

We performed all the analyses using ' $R$ ' version 3.5.2 (R Core Team 2018) with MASS (Venables \& Ripley 2002), MuMIn (Bartón 2013), Ime4 (Bates \& Maechler 2010), Multicomp (Hothorn et al. 2013), vegan (Oksanen et al. 2013) and ape (Paradis \& Schliep 2019) packages.

\section{RESULTS}

\section{Macrophyte monitoring and analysis}

The macrophyte growth at both sites were similar, LI of the two species at the two sites did not show significant differences $(p=0.295$, $g \mathrm{l}=9$ for $\mathrm{S}$. pectinata and $\mathrm{p}=0.458, \mathrm{gl}=7$ for $\mathrm{H}$. nymphoides; Table I); nevertheless, this value was higher at the ES.

The increase in the coverage of S. pectinata at the TS at the end of the experiment was $0.37 \mathrm{~m}^{2}$, while the increase in coverage of $\mathrm{H}$. nymphoides was $0.34 \pm 0.10 \mathrm{~m}^{2}$ (Figure 3 ).

\section{Macroinvertebrate assemblages}

A total of 29 invertebrate taxa were collected from Martín Stream.The most abundant taxa found on S. pectinata during the experiment were Ostracoda (29\%, of total density), Heleobia spp. (21\% of total density), and Hyalella curvispina (17\% of total density). In contrast, the most abundance taxa on $\mathrm{H}$. nymphoides were Hyalella curvispina (15\% of total density), Oligochaeta (13\% of total density), Ostracoda (13\% of total density), and Heleobia spp. (12\% of total density). Twelve taxa were gathering-collectors, eight predators, five scrapers, three filteringcollectors. Free-living aquatic nematodes were not included in the FFG analysis due to the controversies in the FFG classification (Moens et al. 2006) and the scarce number of specimens found.

The results from the linear models indicated that the most important predictor for taxonomic richness and Shannon-Wiener diversity was the site, with a $47 \%$ and a $46 \%$ of the variation respectively ( $w i=0.74$ and $w i=0.80$, Table $I I)$.

Table I. Mean \pm Standard deviation of shoot lengths $(\mathrm{SL}, \mathrm{cm})$ and length increase $(\mathrm{LI}=$ final SL- initial $\mathrm{SL}, \mathrm{cm})$ at the extraction (ES) and transplant (TS) sites during the experiment.

\begin{tabular}{|c|c|c|c|c|c|c|c|c|}
\hline & \multicolumn{6}{|c|}{ SL } & \multirow{2}{*}{\multicolumn{2}{|c|}{ LI }} \\
\hline & \multicolumn{2}{|c|}{ DAY 0} & \multicolumn{2}{|c|}{ DAY 20} & \multicolumn{2}{|c|}{ DAY 40} & & \\
\hline & ES & TS & ES & TS & ES & TS & ES & TS \\
\hline S. pectinata & $\begin{array}{c}6.33 \pm \\
1.51\end{array}$ & $\begin{array}{c}5.80 \pm \\
2.77\end{array}$ & $\begin{array}{c}9.00 \pm \\
4.43\end{array}$ & $9.8 \pm 3.35$ & $\begin{array}{c}11.00 \pm \\
4.82\end{array}$ & $\begin{array}{c}7.80 \pm \\
1.48\end{array}$ & $4.67 \pm 4,63$ & $2.00 \pm 2.91$ \\
\hline H. nymphoides & $\begin{array}{c}29.14 \pm \\
4.37\end{array}$ & $\begin{array}{c}23.75 \pm \\
8.30\end{array}$ & $\begin{array}{c}37.5 \pm \\
16.10\end{array}$ & $27.67 \pm 9.61$ & $\begin{array}{c}35.57 \pm \\
15.39\end{array}$ & $\begin{array}{c}23.00 \pm \\
5.35\end{array}$ & $4.83 \pm 8.13$ & $1.00 \pm 1.00$ \\
\hline
\end{tabular}


In both cases, ES presented significantly higher values for both macrophytes ( $z=-4.76$; $p<$ 0.001; $N=48 ; z=-3.65 ; p<0.001 ; N=48)$. The FFG proportions found are presented in Figure 4. The suitable model for predators indicated that the macrophytes species was the only important predictor, with a $48 \%$ of the variation ( $w i=0.63$; Table II). Hydrocleys nymphoides presented the highest proportion of predators in both sites $(z=2.68 ; p=0.02 ; g l=N=48)$. The variation of the collectors-filterers were explained by the predictor site and the macrophyte ( $w i=0.35$; Table II). However, there were no significant differences between levels. The best model for the proportion of collector-gatherers and scrapers was the null model (Table II). Therefore, the explanatory variables used in the analyzes were poor descriptors of the proportion of these groups.

The macroinvertebrate assemblage composition of each macrophytes across sites during the experiment are shown in Figure 5 ( $P C O A)$. On day 0 , the assemblage of $S$. pectinata at TS was different from the others macroinvertebrate assemblages sampled (Figure 5a). However, the PERMANOVA analysis did not show significant differences between macrophytes and sites on the transplant day (day 0 ). On day 20, only the assemblage of $H$. nymphoides was different between sites (Figure 5b) which was supported by the PERMANOVA results $(F=4.69, p=0.024)$. On day 40 and 60 both macrophytes presented different assemblage between sites (Figure $5 c$ and $5 d$ respectively). However, only the assemblage of $H$. nymphoides on day 40 was significantly different between sites, while the assemblage of $S$. pectinata was significantly different for day $60(F=6.62, p=$ 0.030).

a)

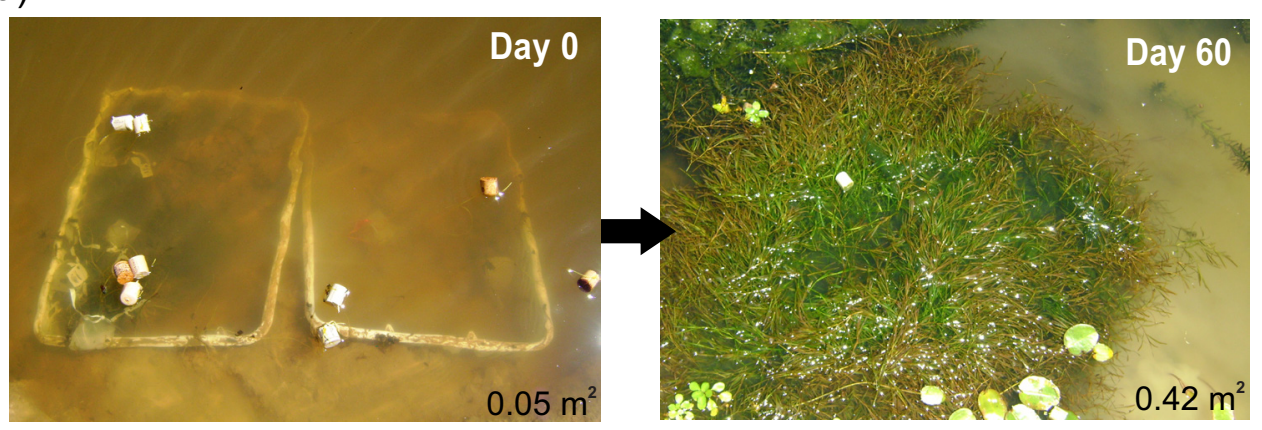

Figure 3. Coverage of the transplanted beds at the transplant site on days 0 and 60 : a) S. pectinata; b) $\mathrm{H}$. nymphoides. Increase in coverage $(\Delta C)$ was calculated as follows: final coverage - initial coverage.

b)

\section{$\Delta C=0.37 \mathrm{~m}^{2}$}
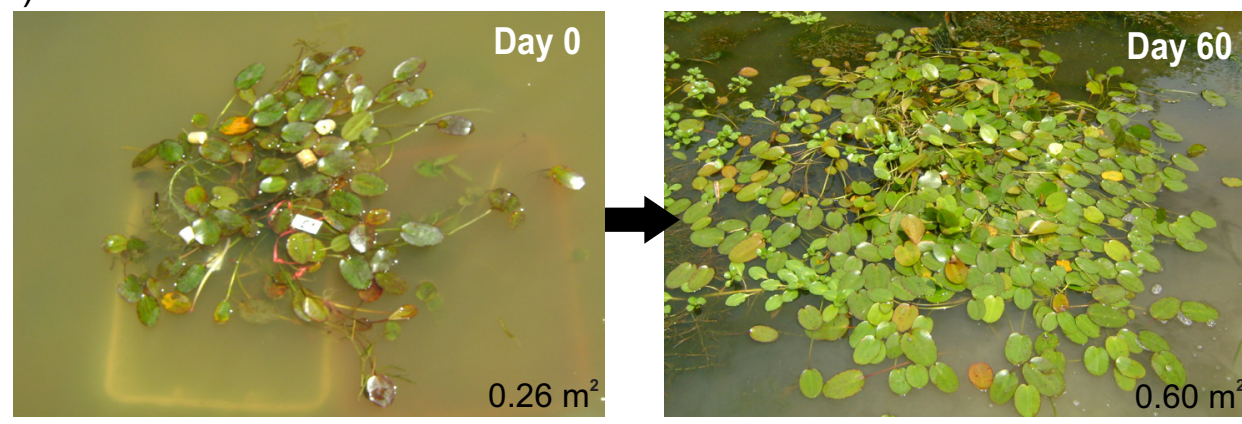

$\Delta C=0.34 \mathrm{~m}^{2}$ 
Table II. The linear models explaining variation in: A- taxonomic richness (GLM), B- Shannon-Wiener diversity (LM), C- predators (GLM), D-.gathering-collectors (GLM), E- Scrapers (GLM), F = filtering-collectors (GLM). The null model, the global model, and models with strong support $(\triangle \mathrm{AICC} \leq 2)$ are provided. Models are listed in decreasing order of importance. $S$ = Site; $M=$ macrophytes; $T=$ time.

\begin{tabular}{|c|c|c|c|c|c|}
\hline Response variable & model & Explanatory variables ${ }^{a}$ & $\triangle \mathrm{AICC}$ & wi & R2 \\
\hline \multirow[t]{4}{*}{$\mathrm{A}=$ taxonomic richness } & 1 & S & 0.00 & 0.74 & 0.47 \\
\hline & 2 & $M+S$ & 2.27 & 0.24 & 0.46 \\
\hline & null & - & 20.96 & 0.00 & - \\
\hline & global & all variables & 23.65 & 0.00 & 0.65 \\
\hline \multirow[t]{3}{*}{$B=$ Shannon-Wiener } & 1 & S & 0.00 & 0.80 & 0.46 \\
\hline & null & - & 3.68 & 0.13 & - \\
\hline & global & all variables & 74.07 & 0.00 & 0.64 \\
\hline \multirow[t]{4}{*}{$\mathrm{C}=$ Predator } & 1 & $M$ & 0 & 0.63 & 0.48 \\
\hline & 2 & $M+S$ & 2.29 & 0.19 & 0.48 \\
\hline & null & - & 4.49 & 0.06 & - \\
\hline & global & all variables & 208.65 & 0.00 & 0.70 \\
\hline \multirow[t]{3}{*}{$\mathrm{D}=$ Collector-gatherers } & null & - & 0.00 & 0.41 & - \\
\hline & 1 & $S$ & 1.07 & 0.24 & 0.05 \\
\hline & global & all variables & 23.34 & 0.19 & 0.66 \\
\hline \multirow[t]{3}{*}{$\mathrm{E}=$ Scrapers } & null & - & 0.00 & 0.45 & - \\
\hline & 1 & $S$ & 1.66 & 0.19 & 0.01 \\
\hline & global & all variables & 26.32 & 0.00 & 0.56 \\
\hline \multirow[t]{5}{*}{$F=$ Collectors-filteres } & 1 & $M+S$ & 0 & 0.35 & 0.28 \\
\hline & 2 & S & 0.57 & 0.26 & 0.14 \\
\hline & 3 & $M+S+T$ & 1.89 & 0.14 & 0.52 \\
\hline & null & - & 3.08 & 0.07 & - \\
\hline & global & all variables & 23.01 & 0.00 & 0.58 \\
\hline
\end{tabular}




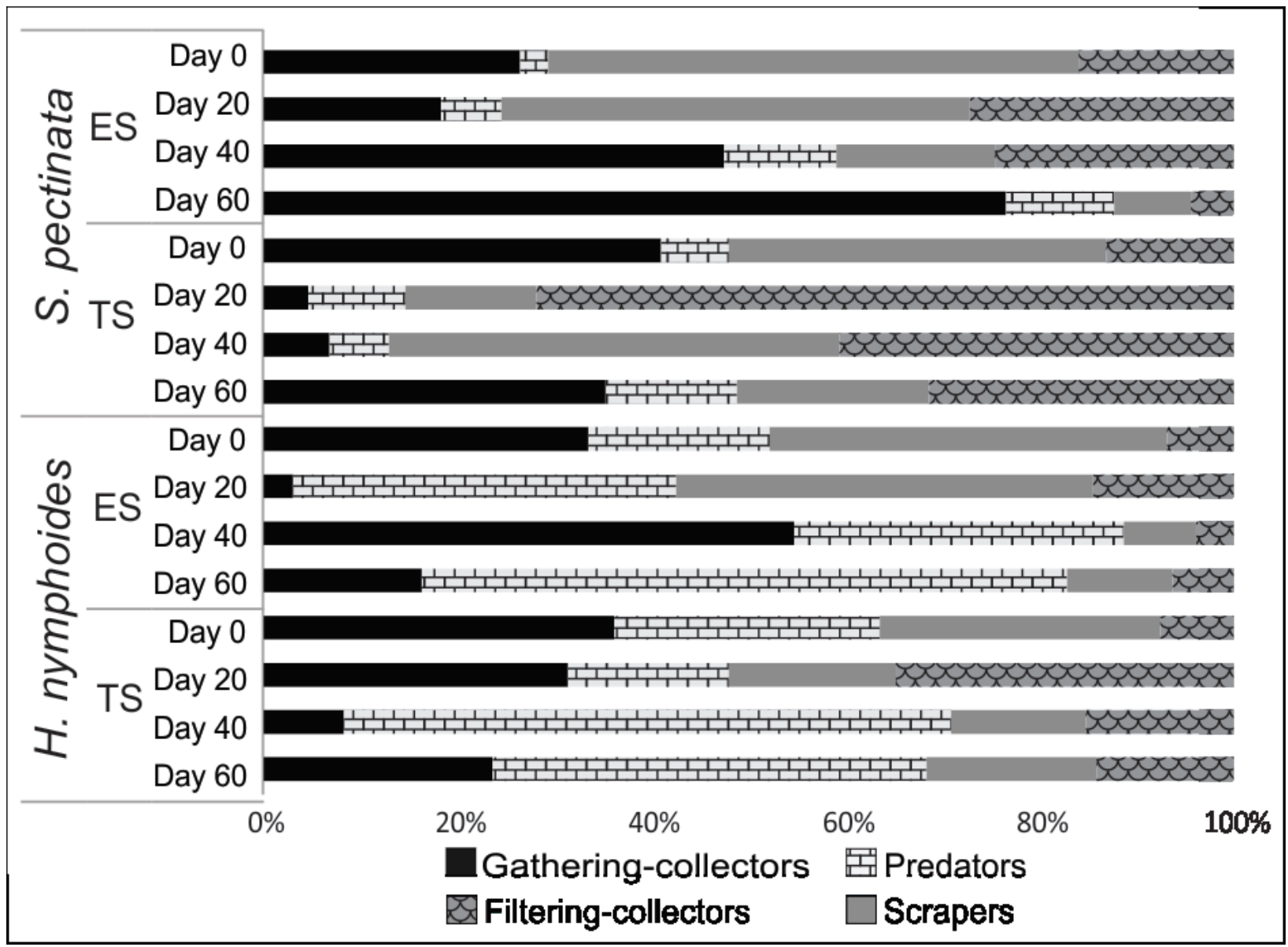

Figure 4. Proportion of functional feeding groups (FFGs) on S. pectinata and H. nymphoides at extraction (ES) and transplant (TS) site for each day.

\section{DISCUSSION}

The relatively quick growth of $\mathrm{S}$. pectinata and H. nymphoides at the transplant site, which was deepened, widened, straightened and their aquatic plants removed, demonstrated that the reintroduction of these macrophytes is possible after a short period of time. This conclusion is based on the similar values of shoot length increase found at both sites and the increase in coverage of transplanted beds during the experiment.

The results found for $S$. pectinata, were in accordance with Larned et al. (2006) that reported similar values for increase in the patch area after 90 days to those we found after 60 days. Moreover, Lauridsen et al. (2003) considered that S. pectinata established itself quickly after transplantation because it anchored easily to the sediment. No studies have used $H$. nymphoides in transplants, which indicates that this experiment is the first approximation of the utilization of this species in a transplant experiment. Evaluating the growth of different macrophytes species after a transplant experiment in lowland streams is essential to improve this technique for future management and rehabilitation projects.

The response and recolonisation of macroinvertebrates assemblage in a short time depends on the availability of source populations of colonists upstream of the 


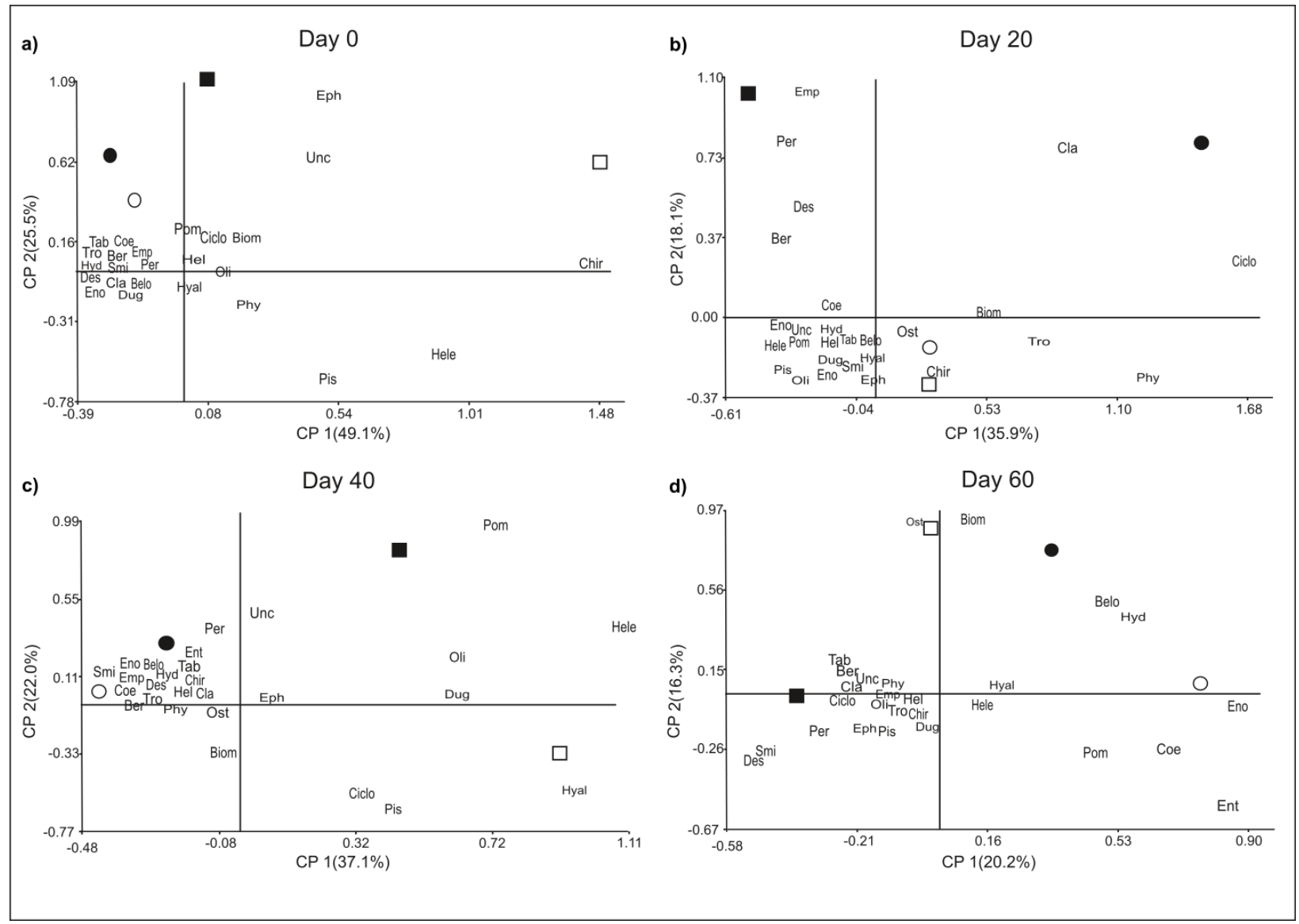

Figure 5. Principal Coordinate Analysis (PCOA) for each day showing the spatial ordination of the two sites (ES: circle and TS: square) and both macrophytes (H. nymphoides: black, S. pectinata: white) in relation to their macroinvertebrate abundance. a) Day 0; b) Day 20; c) Day 40; d) Day 60. Oli: Oligochaeta; Ent: Entomobryidae; Smi: Sminthuridae; Eno: Enochrus sp.; Hyd: Hydrophilus sp.; Ber: Berosus sp.; Tro: Tropisternus sp.; Chir: Chironomidae; Tab: Tabanidae; Eph: Ephydridae; Emp: Empididae; Hyal: Hyalella curvispina; Dug: Dugesiidae; Hel: Helobdellaspp.; Des: Desmopachria sp.; Bel: Belostoma sp.; Per: Perithemis sp.; Coe: Coenagrionidae; Ciclo: Cyclopoidea; Hele: Heleobia spp.; Phy: Physa sp.; Pom: Pomacea canaliculata; Bio: Biomphalaria sp.; Unc: Uncancylus sp.; Pis: Pisidium sp.; Ost: Ostracoda; Cla: Cladocera; Nem: Nematoda.

rehabilitated site (Al-Zankana et al. 2019). Nevertheless, our results showed differences in the structural metrics of the assemblages between sites in a short time despite the presence of a nearly source of specimens. These differences could indicated that the characteristics of the site produced by the river engineering works could be a determining factor in macroinvertebrate assemblage composition. Other authors transplanted macrophytes, and transplanted sections presented low values of diversity and the invertebrate colonization was limited by site features (Larned et al. 2006). Additionally, most studies that improve habitat complexity did not find higher values of richness and diversity of macroinvertebrates (Palmer et al. 2010). Conversely, Miller et al. (2010) and Verdonschot et al. (2016) found significantly higher values of richness and diversity in restored sections of streams but with a longer follow-up period. Therefore, macroinvertebrate structural metrics did not always responds to the increase in habitat heterogeneity at the site, while other aquatic biota may respond. Paz et al. 
(2018) transplanted macrophytes and assessed the change of epiphytic biofilm in a section of the stream affected by river engineering works. These authors found that the biofilm developed in transplanted macrophytes had similar features to those from a non-dredging site after three months. On the other hand, Kail et al. (2015) and Al-Zankana et al. (2019) highlight that the use of functional metrics of macroinvertebrate assemblage would be more appropriate to analyze the effects of restoration measures than structural metrics. In our study, we did not find differences in the proportion of FFGs between extraction and transplanted site, indicating assemblages with similarities in functional composition after three months.

Structural complex macrophytes are often related to higher richness and diversity of macroinvertebrates (Warfe et al. 2008, Bell et al. 2013), because they affect the food supply by trapping detritus, alter epiphyte availability (Phiri et al. 2012), and offer greater protection against possible predators (Dionne \& Folt 1991, Cheruvelil et al. 2002). However we found that richness and diversity did not show differences between macrophytes with different structure complexity, in agreement with the results of McAbendroth et al. (2005) and Ferreiro et al. (2011). On the other hand, we found a higher proportion of predators on the most simple species study ( $H$. nymphoides). However, few studies of the abundance of this group in macrophytes with different complexity have been addressed (Bell et al. 2013, Paice et al. 2015). Both authors found that structurally more complex macrophytes supported a higher density of predators. Nevertheless, many studies have assessed the predation rate, explaining that predation is less frequent in complex macrophytes than in simpler ones, due to the protection against predators (Dionne \& Folt 1991, Cheruvelil et al. 2002, Warfe \& Barmuta 2004).
The structural metrics used in this study were not appropriate for identifying similarities between sites after three months. However, functional metrics could be more suitable to assess the macroinvertebrate assemblage after a rehabilitation project in a short term. Similarly, these metrics could be useful to evaluate differences between macrophytes with different structure complexity. Nevertheless, further research are necessary to assess how functional features respond after restoration measures.

In conclusion, the transplant technique of $S$. pectinata and $H$. nymphoides is feasible and promotes their reintroduction in lowland streams. Transplantation of these macrophytes could be useful as a tool in management and rehabilitation projects to restore the habitat of lowland streams deteriorated by river engineering works. Although, we highlight the importance of incorporating functional traits to assess the ecological status of watercourses after rehabilitation.

\section{Acknowledgments}

This paper is the Scientific Contribution No. 1068 of the Instituto de Limnología-Dr. Raúl A. Ringuelet-(ILPLA, CONICET La Plata, UNLP). This work was carried out within a "Scholarship to Stimulate Scientific Vocations" of the CIN and was supported by the Agency for the Promotion of Science and Technology of Argentina (FONCYT) under the Grant BID PICT 2013-0810, the Faculty of Natural Science and Museum (FCNyM, UNLP) under the Grant N 738 and the National Council for Scientific and Technical Research under the grant PIP 0570.

\section{REFERENCES}

AL-ZANKANA FA, MATHESON T \& HARPER DM 2020. HOW strong is the evidence - Based on macroinvertebrate community responses - That river restoration works? Ecohydrol Hydrobiol 20: 196-214.

ALLAN JD. 2004. Landscapes and riverscapes: the influence of land use on stream ecosystems. Annu Rev Ecol Evol Syst 35: 257-284. 
ALLAN JD \& CASTILLO MM. 2007. Stream ecology: structure and function of running waters. Netherlands: Springer, $435 \mathrm{p}$.

BAL K, STRUYF E, VEREECKEN H, VIAENE P, DE DONCKER L, DE DECKERE E, MOSTAERTB F \& MEIRE P. 2011. How do macrophyte distribution patterns affect hydraulic resistances? Ecol Eng 37: 529-533.

BARBOUR MT, GERRITSEN J, SNYDER BD \& STRIBLING JB. 1999. Rapid Bioassessment Protocols for Use in Streams and Wadeable Rivers: Periphyton, Benthic Macroinvertebrates and Fish, 2nd ed., Washington: EPA Office of water, 197 p.

BARTÓN K. 2013. MuMIn: Multi-Model Inference, version 1.9. 0. R package.

BATES DM \& MAECHLER M. 2010. Ime4: Linear mixed-effects models using S4 classes. R package version 0.999375-36/ r1083.

BELL N, RIIS T, SUREN AM \& BAATTRUP-PEDERSEN A. 2013. Distribution of invertebrates within beds of two morphologically contrasting stream macrophyte species. Fundam Appl Limnol 183/4: 309-321.

BONADA N, PRAT N, RESH VH \& STATZNER B. 2006. Developments in aquatic insect biomonitoring: a comparative analysis of recent approaches. Ann Rev Entomol 51: 495-523.

BONANNO G, BORG JA \& DI MARTINO V. 2017. Levels of heavy metals in wetland and marine vascular plants and their biomonitoring potential: a comparative assessment. Sci Total Environ 576: 796-806.

BROOKER MP. 1985. The ecological effects of channelization. Geogr J 151: 63-69.

BURNHAM KP \& ANDERSON DR. 2002. Model Selection and Multimodel Inference: a Practical Information-theoretic Approach, 2nd ed., New York: Springer-Verlag.

CABRITA MT. 2014. Phytoplankton community indicators of changes associated with dredging in the Tagus estuary Portugal. Environ Pollut 191: 17-24.

CHERUVELIL KS, SORANNO PA, MADSEN JD \& ROBERSON MJ. 2002. Plant architecture and epiphytic macroinvertebrate communities: the role of an exotic dissected macrophyte. J N Am Benthol Soc 21: 261-277.

CHOUDHURY MI, YANG X \& HANSSON LA. 2015. Stream flow velocity alters submerged macrophyte morphology and cascading interactions among associated invertebrate and periphyton assemblages. Aquat Bot 120: 333-337.

COCHERO J, LICURSI M \& GÓMEZ N. 2015. Changes in the epipelic diatom assemblage in nutrient rich streams due to the variations of simultaneous stressors. Limnologica 51: $15-23$.
CORTELEZZI A, SIERRA MV, GÓMEZ N, MARINELLI C \& RODRIGUES CAPítulo A. 2013. Macrophytes, epipelic biofilm, and invertebrates as biotic indicators of physical habitat degradation of lowland streams (Argentina). Environ Monit Assess 185: 5801-5815.

CREMONA F, PLANAS D \& LUCOTTE M. 2008. Biomass and composition of macroinvertebrate communities associated with different types of macrophyte architectures and habitats in a large fluvial lake. FundamAppl Limnol/Archiv für Hydrobiologie 171: 119-130.

CUMMINS KW, MERRITT RW \& ANDRADE PC. 2005. The use of invertebrate functional groups to characterize ecosystem attributes in selected streams and rivers in south Brazil. Stud Neotrop Fauna Environ 40: 69-89.

DIONNE M \& FOLT CL. 1991. An experimental analysis of macrophyte growth forms as fish foraging habitat. Can J Fish Aquat Sci 48: 123-131.

DOS REIS OLIVEIRA PC, KRAAK MH, VERDONSCHOT PF \& VERDONSCHOT RC. 2019. Lowland stream restoration by sand addition: Impact, recovery, and beneficial effects on benthic invertebrates. River Res Appl 35: 1023-1033.

ELOSEGI A, DÍEZ J \& MUTZ M. 2010. Effects of hydromorphological integrity on biodiversity and functioning of river ecosystems. Hydrobiologia 657: 199-215.

ELOSEGI A \& SABATER S. 2009. Conceptos y técnicas en ecología fluvial, Spain: Rubes Editorial, p. 51-70.

ELOSEGI A \& SABATER S. 2013. Effects of hydromorphological impacts on river ecosystem functioning: A review and suggestions for assessing ecological impacts. Hydrobiologia 712: 129-143.

FERREIRO N, FEIJOÓ C, GIORGI A \& LEGGIERI L. 2011. Effects of macrophyte heterogeneity and food availability on structural parameters of the macroinvertebrate community in a Pampean stream. Hydrobiologia 664: 199-211.

GIORGI A, FEIJOÓ C \& TELL G. 2005. Primary producers in a Pampean stream: Temporal variation and structuring role. Biodivers Conserv 147: 1699-1718.

GRYGORUK M, FRĄK M \& CHMIELEWSKI A. 2015. Agricultural Rivers at Risk: Dredging Results in a Loss of Macroinvertebrates. Preliminary Observations from the Narew Catchment, Poland. Water 7: 4511-4522.

GUITTONNY-PHILIPPE A, PETIT ME, MASOTTI V, MONNIER Y, MALLERET L, COULOMB B, COMBROUX I, BAUMBERGERT, VIGLIONE J \& LAFFONT-SCHWOB I. 2015. Selection of wild macrophytes 
for use in constructed wetlands for phytoremediation of contaminant mixtures. J Environ Manage 147: 108-123.

HOTHORN T, BRETZ F \& WESTFALL P. 2013. multcomp: Simultaneous Inference in General Parametric Models. R package version 1. 3-1.

HURTADO MA ET AL. 2006. Análisis ambiental del partido de La Plata, $124 \mathrm{p}$.

KAIL J, BRABEC K, POPPE M \& JANUSCHKE K. 2015. The effect of river restoration on fish, macroinvertebrates and aquatic macrophytes: A meta-analysis. Ecol Indic 58: 311-321.

KJELLAND ME, WOODLEY CM, SWANNACK TM \& SMITH DL. 2015. A review of the potential effects of suspended sediment on fishes: potential dredging-related physiological, behavioral, and transgenerational implications. Environ Syst Decis 35: 334-350.

LARNED ST, SUREN AM, FLANAGAN M, BIGGS BJ \& RIIS T. 2006. Macrophytes in urban stream rehabilitation: establishment, ecological effects, and public perception. Restor Ecol 14: 429-440.

LAURIDSEN TL, SANDSTEN H \& M $\varnothing L L E R P H .2003$. The restoration of a shallow lake by introducing Potamogeton spp.: The impact of waterfowl grazing. Lakes and Reservoirs: Research and Management 8: 177-188.

LEWIS MA, WEBER DE, STANLEY RS \& MOORE JC. 2001. Dredging impact on an urbanized Florida bayou: effects on benthos and algal-periphyton. Environ Pollut 115: 161-171.

LICURSI M \& GÓMEZ N. 2009. Effects of dredging on benthic diatom assemblages in a lowland stream. J Environ Manage 90: 973-982.

LILLIE RA \& BUDD J. 1992. Habitat architecture of Myriophyllum spicatum L. as an index to habitat quality for fish and macroinvertebrates. J Freshw Ecol 7: 113-125.

MCABENDROTH L, RAMSAY PM, FOGGO A, RUNDLE SK \& BILTON DT. 2005. Does macrophytes fractal complexity drive invertebrate diversity, biomass and body size distributions? Oikos 111: 279-290.

MCNETT BJ \& RYPSTRA AL. 2000 Habitat selection in a large orb-weaving spider: vegetational complexity determines site selection and distribution. Ecol Entomol 25: 423-432.

MERRITT RW, CUMMINS KW \& BERG MB. 2008. An introduction to the aquatic insects of North America, 4th ed., Kendall/ Hunt: Dubuque, IA, USA.

MILLENNIUM ECOSYSTEM ASSESSMENT BOARD. 2005. Millennial ecosystem assessment synthesis report. United Nations Environment Programme, New York, USA.
MILLER SW, BUDY P \& SCHMIDT JC. 2010. Quantifying Macroinvertebrate Responses to In-Stream Habitat Restoration: Applications of Meta-Analysis to River Restoration. Restor Ecol 18: 8-19.

MOENS T, TRAUNSPURGER W \& BERGTOLD M. 2006. Feeding ecology of free-living benthic nematodes. Freshwater nematodes: Ecology and Taxonomy 105-131.

OKSANEN J ET AL. 2013. Package 'vegan'. Community ecology package, version, 29.

PAICE RL, CHAMBERS JM \& ROBSON BJ. 2015. Outcomes of submerged macrophyte restoration in shallow impounded, eutrophic river. Hydrobiologia 778: 179-192.

PALMER MA, MENNINGER HL \& BERNHARDT E. 2010. River restoration, habitat heterogeneity and biodiversity: $A$ failure of theory or practice? Freshw Biol 1: 205-222.

PAN G, LI FM \& SUN GJ. 2007. Digital camera based measurement of crop cover for wheat yield prediction. In: GEOSCIENCE AND REMOTE SENSING SYMPOSIUM. IEEE International, p. 797-800.

PARADIS E \& SCHLIEP K. 2019. ape 5.0: an environment for modern phylogenetics and evolutionary analyses in $\mathrm{R}$. Bioinformatics 35: 526-528.

PAZ LE, NICOLOSI GELIS MM, LICURSI M, GÓMEZ N \& RODRIGUES CAPÍTULO A. 2018. Use of native macrophytes for recovery of the habitat structure and complexity of a lowland stream affected by river engineering works: implications for management. River Res Appl 34: 575-585.

PHIRI C, CHAKONA A \& DAY J. 2012. Macroinvertebrates associated with two submerged macrophytes, Lagarosiphon ilicifolius and Vallisneria aethiopica, in the Sanyati Basin, Lake Kariba, Zimbabwe: effect of plant morphological complexity. Afr J Aquat Sci 37: 277-288.

R CORE TEAM. 2018. R: A language and environment for statistical computing. R Foundation for Statistical Computing, Vienna, Austria.

RASBAND W. 1997-2008. ImageJ. U.S. National Institutes of Health, Bethesda, Maryland.

REECE PF \& RICHARDSON JS. 2000. Benthic macroinvertebrate assemblages of coastal and continental streams and large rivers of southwestern British Columbia, Canada. Hydrobiologia 4391-3: 77-89.

RIIS T. 2008. Dispersal and colonization of plants in lowland streams: success rates and bottlenecks. Hydrobiologia 596: 341-351.

RIIS T, SCHULTZ R, OLSEN HM \& KATBORG CK. 2009. Transplanting macrophytes to rehabilitate streams: experience and recommendations. Aquatic Ecol 43: 935. 
RODRIGUES CAPÍTULO A, GÓMEZ N, GIORGI A \& FEIJOÓ C. 2010. Global changes in pampean lowland streams Argentina: implications for biodiversity and functioning. Global Change and River Ecosystems-Implications for Structure, Function and Ecosystem Services 657: 53-70.

SAND-JENSEN K. 1997. Macrophytes as biological engineers in the ecology of Danish streams. In: FRESHWATER BIOLOGY. PRIORITIES AND DEVELOPMENT IN DANISH RESEARCH. København: Gad, p. 74-101.

SPÄNHOFF B \& ARLE J. 2007. Setting attainable goals of stream habitat restoration from a macroinvertebrate view. Restor Ecol 152: 317.

SUREN AM. 2009. Using macrophytes in urban stream rehabilitation: a cautionary tale. Restor Ecol 17: 873-883.

TANIGUCHI H, NAKANO S \& TOKESHI M. 2003. Influences of habitat complexity on the diversity and abundance of epiphytic invertebrates on plants. Freshw Biol 48: 718-728.

VENABLES WN \& RIPLEY BD. 2002 Modern Applied Statistics with S. Fourth Edition. Springer, New York.

VERDONSCHOT RCM, KAIL J, MCKIE BG \& VERDONSCHOT PFM. 2016. The role of benthic microhabitats in determining the effects of hydromorphological river restoration on macroinvertebrates. Hydrobiologia 769: 55-66.

WARFE DM \& BARMUTA LA. 2004. Habitat structural complexity mediates the foraging success of multiple predator species. Oecologia 141: 171-178.

WARFE DM, BARMUTA LA \& WOTHERSPOON S. 2008. Quantifying habitat structure: surface convolution and living space for species in complex environments. Oikos 11712: 1764-1773.

\section{How to cite}

ALTIERI P, PAZ LE, JENSEN RF, DONADELLI J \& CAPÍTULO AR. 2021. Transplanting macrophytes as a rehabilitation technique for lowland streams and their influence on macroinvertebrate assemblages. An Acac Bras Cienc 93: e20191029. DOI 10.1590/0001-3765202120191029.
Manuscript received on August 31, 2019;

accepted for publication on April 13, 2020

PAULA ALTIERI ${ }^{1,2}$

https://orcid.org/0000-0001-6858-8099

LAURA E. PAZ ${ }^{1,2}$

https://orcid.org/0000-0001-5620-553X

\section{ROBERTO F. JENSEN ${ }^{1}$}

https://orcid.org/0000-0001-9795-7789

JORGE DONADELLI ${ }^{1}$

https://orcid.org/0000-0003-2688-0547

ALBERTO RODRIGUES CAPÍTULO

https://orcid.org/0000-0002-6133-3920

${ }^{1}$ Instituto de Limnología, Dr.-Raúl A. Ringuelet (ILPLA)

(CONICET La Plata, UNLP) C.C 712-1900, La Plata, Argentina

${ }^{2}$ Facultad de Ciencias Naturales y Museo, Universidad

Nacional de La Plata. C.C 712-1900, La Plata, Argentina

Correspondence to: Paula Altieri

E-mail: altieripaula@ilpla.edu.ar

\section{Author contributions}

P. Altieri and L.E. Paz: Conceptualization, Methodology, Formal analysis, Investigation, Writing. R. F. Jensen and J. Donadelli: Methodology. A. Rodrigues Capítulo: Conceptualization, Investigation, Funding acquisition, Supervision.

(cc) BY 